\title{
Effect of chemical and biological seed treatments on common bean seeds inoculated with Fusarium oxysporum f. sp. phaseoli
}

\section{Efeito de tratamentos químicos e biológicos de sementes em sementes de feijoeiro inoculadas com Fusarium oxysporum $f$. sp. phaseoli}

\author{
Mariane Sayuri Ishizuka1* (1) (orcid.org/0000-0001-8076-4075) \\ Renata Rebellato Linhares de Castro ${ }^{1}$ (1) (orcid.org/0000-0001-9488-7164) \\ Maria Heloisa Duarte de Moraes ${ }^{1}$ (1) (orcid.org/0000-0001-6820-3929) \\ José Otavio Machado Menten' (1D) (orcid.org/0000-0002-9644-5770)
}

\begin{abstract}
Currently, the common bean (Phaseolus vulgaris L.) productivity has been reduced by the fungus Fusarium oxysporum f. sp. phaseoli (Fop), the causative agent of Fusarium wilt. Considering the integrated management of diseases, the objectives of the present work were to verify the compatibility between chemical and biological fungicides for Fusarium oxysporum Schlecht. f. sp. phaseoli Kendrick \& Snyder (Fop) control in common bean seeds. In laboratory, the effects of the treatments were evaluated by sanity, germination, seedling total length and seedling dry matter tests. In greenhouse conditions, the emergence speed rate, the percentage of emergence and the rate of pathogen transmission through the pathogen infestation in a substrate to plants were evaluated. Common bean seeds BRS Estilo were artificially inoculated with Fop isolate (IAC 11.299-1). In the seeds' treatment, the chemical fungicides fludyoxonyl, flutriafol, methyl tiofanate, and biological products of Trichoderma sp. (isolates SF04, GF 422 and strain 1306), separately and mixed, were used. Treatments that promoted the best pathogen control in seeds were the combination of methyl tiophanate with biological products. Both flutriafol and GF 422 isolated and in mixed treatments affected the seeds' physiological quality. The protective effect of the products was noted in the transmission test, whose Fop incidence was from 5 to $40 \%$ in the hypocotyl and from 5 to $30 \%$ in common bean roots.
\end{abstract}

KEYWORDS: Phaseolus vulgaris; biological control; physiological quality; seed pathology; integrated management.

\begin{abstract}
RESUMO: Atualmente, a produtividade do feijão comum (Phaseolus vulgaris L.) foi reduzida pelo fungo Fusarium oxysporum f. sp. phaseoli (Fop), o agente causador da murcha de Fusarium. Considerando o manejo integrado de doenças, os objetivos do presente trabalho foram verificar a compatibilidade entre fungicidas químicos e biológicos para Fusarium oxysporum Schlecht. f. sp. phaseoli Kendrick \& Snyder $(F o p)$ em sementes de feijão. Em laboratório, foram avaliados os efeitos dos tratamentos pelos testes de sanidade, germinação, comprimento total de plântulas e matéria seca de plântulas. Em uma estufa, foram avaliadas a velocidade de emergência, a porcentagem de emergência e a taxa de transmissão de patógenos através da infestação de patógenos no substrato às plantas. As sementes de feijão comum BRS Estilo foram inoculadas artificialmente com isolado Fop (IAC 11.299-1). No tratamento das sementes, foram utilizados os fungicidas químicos fludioxoxil, flutriafol, tiofanato metílico e produtos biológicos de Trichoderma sp. (isolados SF04, GF 422 e cepa 1306), separadamente e misturados. Os tratamentos que promoveram o melhor controle de patógenos nas sementes foram a combinação de tiofanato de metila com produtos biológicos. Tanto o flutriafol quanto o GF 422 isolados e em tratamentos com misturas afetaram a qualidade fisiológica das sementes. $\mathrm{O}$ efeito protetor dos produtos foi observado no teste de transmissão, cuja incidência de Fop foi de 5 a 40\% no hipocótilo e de 5 a 30\% nas raízes do feijão comum.
\end{abstract}

PALAVRAS-CHAVE: Phaseolus vulgaris; controle biológico; qualidade fisiológica; patologia de sementes; manejo integrado.

\footnotetext{
'Universidade de São Paulo Escola Superior de Agricultura Luiz de Queiroz - Piracicaba (SP), Brazil. *Corresponding author: marianeishizuka@yahoo.com.br, ishizuka.mariane@gmail.com
} Received on: 05/27/2018. Accepted on: 01/27/2020 


\section{INTRODUCTION}

Common bean (Phaseolus vulgaris L.) is a legume whose grains make up an important protein source for human consumption. Brazil is its third largest world producer with an annual mean production of 3 million tons of grains, surpassed by India (6.4 million tons) and Myanmar (5.4 million tons) (FAOSTAT, 2017). The national geographic distribution of the main producers is relatively observed in several states, although the main ones are: Paraná (21\%), Minas Gerais (19\%), Mato Grosso (11\%), Goiás (10\%), and São Paulo $(6 \%)$, which currently produce $67 \%$ of the Brazilian production (CONAB, 2019). Small and medium-sized farms are responsible for $60 \%$ of grain production, and farmers often choose to grow beans as a short-term income alternative over the main activities. The predominantly used cultivars belong to the commercial class "Carioca", which has large national demand (GUIMARÃES; SOUZA, 2019) and, however, is susceptible to several diseases caused by pathogens (COMISSÃO TÉCNICA SUL-BRASILEIRA, 2012).

Among the complex of soil-borne pathogens that affect bean crops, the fungus Fusarium oxysporum Schlecht. f. sp. phaseoli Kendrick \& Snyder (Fop) is known as the causal agent of Fusarium wilt. This disease has become a problem mainly in areas with successive bean cultivation under irrigation systems via central pivot and in soils with no-tillage (DHINGRA; NETTO, 2001; PAULA JÚNIOR et al., 2004).

In the case of Fusarium wilt, common bean seeds are an important source of inoculum and can carry the pathogen externally, in the form of spores attached to the surface of the integument, or internally, as a dormant mycelium (MACE et al., 1981; VIEIRA, 1993). In terms of management, seed treatment is a viable measure for the control of vascular wilt, because, in addition to reducing the inoculum carried by the seeds, it also offers partial protection to the seeds and seedlings against pathogens present in the soil, in its initial phase of development (VANIN et al., 2011).

Currently, the adoption of alternative methods of control plays a relevant role in integrated disease management. In Brazil treated area with Trichoderma spp. has grown in recent decades and its use is directly related to the adoption of sustainable measures in modern agriculture (MORANDI; BETTIOL, 2009). This fungal genus has shown great potential as a biological agent in seed microbiolization, reducing the exclusive use of chemical fungicides, and also preventing the development of resistance by pathogens to these products (MELO, 1991).

Considering that there are few studies that correlate the interaction between chemical and biological products, aiming, especially, at the management of Fusarium wilt, this work had the objective of verifying the compatibility of chemical and biological fungicides for seed treatment aiming to control
Fop, from artificially inoculated seeds and under condition of soil infestation with the pathogen.

\section{MATERIAL AND METHODS}

The experiments were performed in the Seed Pathology Laboratory and in a greenhouse, both at the Department of Plant Pathology and Nematology, located at Escola Superior de Agricultura "Luiz de Queiroz" at Universidade de Sáo Paulo (ESALQ-USP), in Piracicaba, São Paulo state, from an altitude of $546 \mathrm{~m}$.

For all the assays, healthy common bean seeds (Phaseolus vulgaris $\mathrm{L}$.) were used, cultivar BRS Estilo, classified into commercial class "Carioca" and susceptible to Fusarium oxysporum f. sp. phaseoli. Seeds were previously subjected to superficial asepsis ( 3 minutes with $1 \%$ sodium hypochlorite) and, subsequently, dried for two days on an aseptic surface.

Isolate IAC 11.299-1 of F oxysporum, provided by Instituto Agronômico de Campinas (IAC), previously preserved in potatodextrose-agar (PDA) culture medium, was used. Mycelial plugs ( $5 \mathrm{~mm}$ diameter) of the pathogen were placed in the center of Petri dishes containing PDA culture medium. Then, these Petri dishes were kept in an incubation chamber, at $20 \pm 2^{\circ} \mathrm{C}$, alternating $12 \mathrm{~h}$ under white fluorescent light and $12 \mathrm{~h}$ in the dark, for a period of seven days.

Seed inoculation was performed using the water restriction technique of PDA+ mannitol at 1.0 MPa medium culture, as described by COSTA et al. (2003). Common bean seeds remained in contact with Fop colonies grown in this medium, stored in an incubation chamber at $20 \pm 2^{\circ} \mathrm{C}$ for six hours with white fluorescent light, and then, were put in aseptic containers for 48 hours drying at room temperature. Seeds inoculated with Fop were mixed with healthy seeds, in the proportion of 1:2 (inoculated/healthy), immediately before being treated with chemical and biological products. The active ingredients used were fludioxonyl, flutriafol and tiophanate methyl, and three isolates of Trichoderma spp., two of which are the T. asperellum species, provided by the company Grupo Farroupilha Ltda. (products based on SF04 and GF 422), and another product based on Trichoderma sp., strain 1306, provided by Koppert Brasil.

Treatments were divided into fungicides, biological products and both combination of them. Seeds were treated with fungicides according to the manufacturer's recommendations (Table 1). The application consisted of placing the product solution in a plastic bag, adding the seeds and stirring manually until complete distribution. This procedure occurred before assembling the tests. Two controls were included, one represented by seeds without pathogen and the other represented by seeds inoculated with Fop. 


\section{Laboratory trials}

Immediately after the application, seeds were submitted to the following tests:

- Sanity test: it was carried out through the blotter-test method, according to the Analysis Manual of Seed Sanity (BRASIL, 2009a), using four replicates of 50 seeds, wrapped individually in plastic Petri dishes, in three blotter-test discs moistened with distilled water, spaced 1-2 $\mathrm{cm}$ apart from one another. Later, the seeds were kept in an incubation chamber, at $20 \pm 2^{\circ} \mathrm{C}$, alternating $12 \mathrm{~h}$ under white fluorescent light and $12 \mathrm{~h}$ in the dark, for a period of seven days. To detect fungi, the seeds were examined individually under a stereomicroscope, resolution 30-80X. Whenever necessary, the pathogen's identity was confirmed through the observation slides under an optical microscope, with the aid of the literature available. The results were expressed as the percentage of occurrence of Fop incidence in the seeds.

- Germination: four subsamples of 50 seeds were used per replication/treatment, distributed on paper towels ('germitest') moistened with water equivalent to twice and half the weight of the dry paper. Rolls were made and placed into plastic bags and left for germination at $25^{\circ} \mathrm{C}$. After five days of incubation, the first germination count was performed, considering the number of normal seedlings and the results expressed as their mean percentage. After nine days, the final germination count was performed, determining the percentage of normal seedlings, abnormal seedlings and dead seeds, according to Rules for Seeds Analysis (BRASIL, 2009b).

- Seedling length: four subsamples of ten seeds per replication per treatment were sown in a line drawn on paper towels ('germitest') moistened with water equivalent to twice the weight of the dry paper (NAKAGAWA, 1999). Seeds were positioned so that the micropile was facing the bottom of the paper. Rolls were made and placed into plastic bags and left for germination in an upright position at $25^{\circ} \mathrm{C}$ for 5 days (NAKAGAWA, 1999). At the end of this period, the parts of the normal seedlings that emerged were measured using a ruler. The averages of the lengths of primary root, hypocotyl and total seedlings were expressed in centimeters.

- Seedling dry matter: normal seedlings from the seedling length test were placed in paper bags and dried in an oven at $80^{\circ} \mathrm{C}$ for $24 \mathrm{~h}$. Results were obtained dividing each weight by the number of normal seedlings (NAKAGAWA, 1999). Then, the means were obtained for each treatment, using a precision scale and the averages for each treatment expressed in grams.

\section{Greenhouse trials}

Tests were conducted in uncontrolled conditions and, according to the Piracicaba meteorological station, during the period the average air temperatures were, respectively, 21, 23.6 and $25.4^{\circ} \mathrm{C}$, in the months of August, September and October 2015.

Sowing was carried out in polypropilene plastic boxes (CaixaPlast brand) with a capacity of 5 liters, containing commercial substrate Basaplan ${ }^{\circledR}$. Four replicates were sown with 50 common bean seeds in each box per treatment, watering every day. Subsequently, evaluations were carried out to obtain the following data:

Emergence speed index (ESI): counts were performed daily, considering seedlings that presented the first pair of unifoliate leaves were completely open, until the number of seedlings was stabilized. The ESI was calculated according to the formula proposed by MAGUIRE (1962), in which ESI=N1/ $\mathrm{D} 1+\mathrm{N} 2 / \mathrm{D} 2+\ldots+\mathrm{Nn} / \mathrm{Dn}$, where: ESI seedling emergence speed index; $\mathrm{N}=$ number of seedlings emerged and computed from the first to the last count; $\mathrm{D}=$ number of days from sowing to the last count.

Emergence percentage: seedlings count emerged at 8 and 16 days after sowing, the absolute value being transformed into a percentage.

Determination of transmission rate of the infested substrate: inoculum preparation and treatment of the seeds with the products were carried out as previously described.

Table 1. Commercial names of chemical and biological products, active ingredients, concentration of active ingredients, and dose used in common bean seed treatment for Fop controlling.

\begin{tabular}{|c|c|c|c|}
\hline Commercial product & Active ingredient & $\begin{array}{l}\text { I. a. concentration } \\
\left(\mathrm{g} . \mathrm{L}^{-1}\right)\end{array}$ & Dose of c.p. $.^{(1)} / \mathrm{kg}$ of seeds \\
\hline Maxim & Fludyoxonyl & 25 & $2 \mathrm{~mL}$ \\
\hline Vincit $50 \mathrm{SC}$ & Flutriafol & 50 & $1 \mathrm{~mL}$ \\
\hline Cercobin 700 WG & Tiophanate methyl & 700 & 1 gram \\
\hline SF 04 & T. asperellum & $1 \times 10^{10} \mathrm{cfu} / \mathrm{g}$ & 1 gram \\
\hline GF 422 & T. asperellum & $1 \times 10^{10} \mathrm{cfu} / \mathrm{g}$ & 1 gram \\
\hline Strain 1306 & Trichoderma sp. & $4 \times 10^{9}$ viable conidia/mL & $2 \mathrm{~mL}$ \\
\hline
\end{tabular}

${ }^{(1)}$ C.p.: commercial product. 
Fop infestation in the soil was based on the methodology of CHAUDHARY et al. (2006). Pots with a capacity of $2 \mathrm{~L}$ were used, which were filled with the commercial substrate Basaplan $^{\circledR}$, at a depth of $10 \mathrm{~cm}$. Afterward, a $2 \mathrm{~cm}$ layer of vermiculite was deposited, Fop colonies on the surface until full coverage, and a last layer of $1 \mathrm{~cm}$ of vermiculite. Ten common bean seeds were sown in each pot, covered with a $2 \mathrm{~cm}$ layer of vermiculite and the pots were irrigated. The control treatment consisted of healthy seeds, without any chemical and biological products. To determine the rate of transmission, fragments of about $3 \mathrm{~cm}$ were removed from the primary root region and the hypocotyl region of asymptomatic and symptomatic plants, in stage V4. Then, these fragments were subjected to asepsis in $70 \%$ alcohol for 30 seconds, then emerged in 1\% sodium hypochlorite for 30 seconds, rinsed twice in sterile distilled water and placed in Petri dishes with PDA culture medium. Petri dishes were kept in an incubation chamber at $20^{\circ} \mathrm{C}$ and photoperiod of 12 hours. All fragments were examined every day, where it was possible to observe mycelia growing on its surface after three days of incubation. The transmission rate was obtained considering the number of fragments with mycelia growth according to the number of plants evaluated in each pot. The result was expressed as a percentage of infected fragments.

\section{Statistics analysis}

The experimental design was completely randomized, for the tests performed in laboratory conditions, and the randomized block design, for greenhouse testing.

The data were subjected to the analysis of variance (ANOVA) and the means were compared using the ScottKnott test $(\mathrm{p}<0.05)$. For the transmission test results, the transformation $\sqrt{x}_{\mathrm{x}} 1$ was made for the percentages obtained in the plant hypocotyl and the transformation arc sen $V_{x} / 100$ for the data obtained in the main root. All analyses were performed using the statistical program Assistat 7.7 beta version (SILVA; AZEVEDO, 2002).

\section{RESULTS AND DISCUSSION}

After Fop inoculation, the incidence of $88 \%$ of the pathogen in common bean seeds was obtained. All treatments, assessed by the Blotter test, proved to be efficient in controlling the pathogen, except for flutriafol, whose incidence percentage did not differ from the inoculated control and presented only 9\% of seed control (Table 2).

It was observed that the control of $F$. oxysporum was variable between treatments, and biological agents, when used alone, reduced the incidence of the pathogen by 66 to $68 \%$. For chemical fungicides, which significantly reduced the incidence, the control was 25 to $30 \%$ (Table 2). This shows that, in some cases, Trichoderma spp. may be more efficient in controlling soil-borne pathogens that fungicides. In Brazil, however, it is known that until them, some studies have reported that fungicides are more efficient than biological products in eradicating pathogens associated with seeds. In this regard, CARVALHO et al. (2011), when evaluating six isolates of Trichoderma harzianum identified that isolates CEN202, CEN234, CEN238, and CEN 240 reduced the incidence of $F$ oxysporum between 35 and $51 \%$ in common bean seeds. The control promoted by such isolates did not exceed the fungicide carboxin+thiram, which was responsible for the $73 \%$ reduction in the incidence of pathogens. In soybean seeds, MERTZ et al. (2009) verified that the treatments with carbendazim+thiram, carboxin+thiram, and difenoconazole+metaxyl were more efficient than Biotrich (Trichoderma spp.) product, for controlling Phomopsis spp. and Fusarium spp.

Chemical fungicides, once combined with biological products, were able to significantly reduce the incidence of Fop. The mixture of methyl thiophanate with biological products was the most efficient in controlling the pathogen, reducing between 91 and 95\% the incidence of Fop in the seeds (Table 2).

Table 2. Effect of chemical and biological treatments in sanitary quality of common bean seeds artificially inoculated with Fop.

\begin{tabular}{lcc} 
Treatment & $\begin{array}{c}\text { Fop } \\
\text { incidence } \\
(\%)\end{array}$ & $\begin{array}{c}\text { Pathogen } \\
\text { control (\%) }\end{array}$ \\
\hline Untreated control & $88 \mathrm{a}$ & - \\
\hline Fludyoxonyl & $66 \mathrm{~b}$ & 25 \\
\hline Flutriafol & $80 \mathrm{a}$ & 9 \\
\hline Tiophanate methyl & $62 \mathrm{~b}$ & 30 \\
\hline SF 04 & $30 \mathrm{c}$ & 66 \\
\hline GF 422 & $28 \mathrm{c}$ & 68 \\
\hline Strain 1306 & $28 \mathrm{c}$ & 68 \\
\hline Fludyoxonyl+SF 04 & $34 \mathrm{c}$ & 61 \\
\hline Fludyoxonyl+GF 422 & $30 \mathrm{c}$ & 66 \\
\hline Fludyoxonyl+strain 1306 & $20 \mathrm{c}$ & 77 \\
\hline Flutriafol+SF 04 & $54 \mathrm{~b}$ & 38 \\
\hline Flutriafol+GF 422 & $42 \mathrm{c}$ & 52 \\
\hline Flutriafol+strain 1306 & $58 \mathrm{~b}$ & 34 \\
\hline Tiophanate methyl+SF 04 & $4 \mathrm{~d}$ & 95 \\
\hline Tiophanate methyl+GF 422 & $8 \mathrm{~d}$ & 91 \\
\hline Tiophanate methyl+strain 1306 & $6 \mathrm{~d}$ & 93 \\
\hline Mean & 39.34 & \\
\hline C.V. (\%) & 27.57 & \\
\hline & & \\
\hline
\end{tabular}

Means followed by the same letter in the column do not differ by the Scott-Knott test $(p<0.05)$; CV: coefficient of variation. 
As for the association between flutriafol and biological products (SF 04, GF 422, and strain 1306), the Fop incidences were, respectively, 54, 42, and 58\%. Although these combinations did not promote equivalent control to biological fungicides alone, it is worth noting that there was higher control of the pathogen compared to treatment with flutriafol alone, whose Fop incidence was $80 \%$ (Table 2).

In terms of sanitary quality, it is inferred that biological agents, when combined with chemical fungicides, can raise the potential effect of controlling promoted by chemicals, suppressing the development of the pathogen. HOWELL (2007) reports the protective effect of the combination of Trichoderma virens with fungicides in cotton seeds, in the control of Pythium sp. and Rhizoctonia solani. The percentage of healthy seeds was higher than the untreated control in combinations of isolate G-6 with chloroneb $(93 \%)$, chloroneb+metalaxyl $(80 \%)$, carboxin $(60 \%)$, and carboxin+PCNB (53\%).

Other studies point to the potential association of chemical and biological fungicides, such as carboxin+thiram with Agrotrich (Trichoderma spp.), which totally eradicated the incidences of Penicillium spp., Fusarium spp., and Aspergillus spp. in soybean seeds (BRAND et al., 2009). In wheat seeds, the combination of difenoconazole and Paenibacillus macerans significantly reduced Fusarium graminearum, Bipolaris sorokiniana, Drechslera tritici, and Aspergillus spp. This combination also promoted an increase in germination and grain yield in field conditions (LUZ, 2003). The same author states in another work that $P$. macerans associated with fludyoxonyl+metalaxyl-M completely eliminated $F$. graminearum, F. verticillioides, Diplodia maydis, and Aspergillus spp. in corn seeds.

According to Table 3, 66\% of seed germination was obtained in the inoculated control, differing from the non-inoculated one. Most treatments did not differ from the non- inoculated control, indicating that the control of the pathogen, even though it was not $100 \%$, resulted in increased germination of the inoculated seeds. The treatments GF 422 and flutriafol+GF 422 impaired seed germination, reflecting the higher number of abnormal seedlings and dead seeds, despite reducing the incidence of the pathogen in the seeds (Table 3).

In this study, the presence of isolated SF 04 and strain 1306 recovered the germination of common bean seeds, whose increase was 20 to $24 \%$ compared to the inoculated control, probably as an effect of the reduction in the pathogen incidence (Table 3). In common bean seeds inoculated with Fop and biological antagonists, ALWATHNANI et al. (2012) state that the biocontrol promoted by them increased seed germination by $30 \%$; the authors observed that the maximum percentage was obtained with Trichoderma harzianum (90\%), followed by T. viride (58\%) and Aspergillus niger (33\%).
The highest lengths of primary root and total length of seedlings were obtained in the treatments: fludyoxonyl, all biological products, fludyoxonyl+SF 04, fludioxonil+GF 422, and tiofanate methyl+SF 04 (Table 4). As for the length of the hypocotyl, it is observed that in treatments with tiofanate methyl, SF 04, GF 422, fludyoxonyl+SF 04, and fludyoxonyl+GF422 the length was longer than the healthy and inoculated controls, although there was no statistical difference between both controls (Table 4). Regarding the seedlings' dry matter, the values obtained with the treatments thyophanate-methyl, SF 04, GF 422, fludioxonyl+GF 422, and thyophanate methyl+GF 422 were superior to the healthy and inoculated controls. In this evaluated parameter, such treatments promoted an increase, on average, of $54 \%$ in dry matter (Table 4 ).

In greenhouse conditions, it was verified that treatments with fludyoxonyl, thyophanate methyl, fludyoxonyl +strain 1306, thyophanate methyl+GF422, and thyophanate methyl+strain 1306 showed a positive effect on the ESI, behaving statistically equal to the healthy control. Seedling percentage at 8 days after sowing did not describe the treatments. However, it was noticed that, after 16 days, the treatments fludyoxonyl, SF 04, strain 1306, fludyoxonyl+SF 04, fludyoxonyl+GF 422,

Table 3. First count, germination, abnormal seedlings, and dead seeds in the germination test of common bean seeds 'BRS Estilo' inoculated artificially with Fop and treated with chemical and biological products.

\begin{tabular}{lcccc} 
Treatment & FC\% & G\% & AS\% & DS\% \\
\hline Healthy control & $78 \mathrm{a}$ & $82 \mathrm{a}$ & $18 \mathrm{~b}$ & Ob \\
\hline Inoculated control & $60 \mathrm{~b}$ & $66 \mathrm{~b}$ & $26 \mathrm{a}$ & $8 \mathrm{a}$ \\
\hline Fludyoxonyl & $67 \mathrm{a}$ & $76 \mathrm{a}$ & $14 \mathrm{~b}$ & $10 \mathrm{a}$ \\
\hline Flutriafol & $56 \mathrm{~b}$ & $68 \mathrm{~b}$ & $18 \mathrm{~b}$ & $14 \mathrm{a}$ \\
\hline Tiophanate methyl & $71 \mathrm{a}$ & $80 \mathrm{a}$ & $12 \mathrm{~b}$ & $8 \mathrm{a}$ \\
\hline SF 04 & $72 \mathrm{a}$ & $78 \mathrm{a}$ & $14 \mathrm{~b}$ & $8 \mathrm{a}$ \\
\hline GF 422 & $56 \mathrm{~b}$ & $58 \mathrm{c}$ & $30 \mathrm{a}$ & $12 \mathrm{a}$ \\
\hline Strain1306 & $73 \mathrm{a}$ & $76 \mathrm{a}$ & $18 \mathrm{~b}$ & $6 \mathrm{a}$ \\
\hline Fludyoxonyl+SF 04 & $60 \mathrm{~b}$ & $76 \mathrm{a}$ & $10 \mathrm{~b}$ & $14 \mathrm{a}$ \\
\hline Fludyoxonyl+GF 422 & $57 \mathrm{~b}$ & $72 \mathrm{a}$ & $14 \mathrm{~b}$ & $14 \mathrm{a}$ \\
\hline Fludyoxonyl+strain 1306 & $74 \mathrm{a}$ & $78 \mathrm{a}$ & $12 \mathrm{~b}$ & $10 \mathrm{a}$ \\
\hline Flutriafol+SF 04 & $67 \mathrm{a}$ & $82 \mathrm{a}$ & $16 \mathrm{~b}$ & $2 \mathrm{~b}$ \\
\hline Flutriafol+GF 422 & $46 \mathrm{c}$ & $56 \mathrm{c}$ & $26 \mathrm{a}$ & $18 \mathrm{a}$ \\
\hline Flutriafol+strain 1306 & $67 \mathrm{a}$ & $76 \mathrm{a}$ & $12 \mathrm{~b}$ & $12 \mathrm{a}$ \\
\hline Tiophanate methyl+SF 04 & $66 \mathrm{a}$ & $80 \mathrm{a}$ & $8 \mathrm{~b}$ & $12 \mathrm{a}$ \\
\hline Tiophanate methyl+GF 422 & $45 \mathrm{c}$ & $68 \mathrm{~b}$ & $20 \mathrm{~b}$ & $12 \mathrm{a}$ \\
\hline Tiophanate methyl+strain 1306 & $73 \mathrm{a}$ & $80 \mathrm{a}$ & $12 \mathrm{~b}$ & $8 \mathrm{a}$ \\
\hline Mean & $63 \mathrm{~b}$ & $74 \mathrm{a}$ & $16 \mathrm{~b}$ & $5.27 \mathrm{a}$ \\
\hline CV (\%) & 11.20 & 9.57 & 32.89 & 28.86 \\
\hline & & & \\
\hline
\end{tabular}

Means followed by the same letter in the column do not differ by the Scott-Knott test ( $p<0.05)$; FC\%: first count; G\%: germination; AS\%: abnormal seedlings; DS\%: dead seeds; CV: coefficient of variation. 
fludyoxonyl+strain 1306, flutriafol+SF 04, flutriafol+strain 1306, thyophanate methy+GF 422, and thyophanate methyl+strain 1306 promoted an increase in seedling emergence, differing from inoculated seeds, but not from non-inoculated control (Table 5). This result disagrees with MERTZ et al. (2009) when evaluating the effect of chemical and biological fungicides applied to soybean seeds. In this work, the emergence of plants was severely impaired, especially with Trichoderma spp., resulting in $17 \%$ of emergence. In this case, better results were obtained with carbendazim+thiram, which ensured an emergence of $78 \%$, followed by carboxin+thiram treatment (57\%).

It was observed that the results generated in the emergence percentage test at the greenhouse correspond to the ones obtained from the germination test at laboratory conditions, where two treatments (flutriafol and GF 422) did not differ from the inoculated control.

Physiological quality parameters did not show the effect of treatments in the same way, except for SF 04 and fludyoxonyl+GF422, which stood out not only in the tests of hypocotyl length and primary root and dry matter weight (Table 4), but also showed good performance in the germination test and percentage of seedlings emergence at 8 days (Table 5). Based on these results, it is inferred that seed treatment, once done with appropriate products, is able to increase the vigor of the plants. Consequently, plants will have better development and higher tolerance against adversities faced in the field (EL-ABYAD et al., 1993). According to CANTERI et al. (1999) common bean plants with higher ESI, dry matter weight, both root and shoot, become less sensitive to soilborne pathogens attack, caused by Sclerotinia sclerotiorum, Fusarium oxysporum $\mathrm{f}$. sp. phaseoli, Fusarium solani, and others.

However, it is worth to emphasize that seed treatment does not essentially aim to increase germination percentage and seedling emergence, but to reduce the rate of transmission of pathogens associated with seeds to the lowest possible levels (FORCELINI, 1991).

In the pathogen transmission test from the infested substrate to common bean seedlings, there was more Fop colonization in the hypocotyl region (42.5\%) compared to the root region (30\%). The lowest percentage of Fop transmission was observed in the hypocotyl of seedlings whose seeds were treated with fludyoxonyl, tiophanate methyl, GF 422, strain 1306, fludyoxonyol+GF422, and tiophanate methyl +GF422 (Fig. 1). Regarding Fop infection in the roots, greater protection was obtained with the treatments: fludyoxonyl, SF 04, strain 1306, fludyoxonyl+GF 422, fludyoxonyl+strain 1306, flutriafol+SF 04 , and tiophanate methyl +GF 422 (Fig. 2). In this trial, fludyoxonyl, strain 1306, fludyoxonyol+GF422, and tiophanate methyl+GF422 stood out in the control of Fop both in roots and shoot.

Table 4. Primary root, shoot and total seedlings length and seedling dry matter obtained from common bean seeds 'BRS Estilo' inoculated artificially with Fop and treated with chemical and biological products.

\begin{tabular}{lcccc}
\hline Treatment & PR (cm) & S (cm) & TSL $(\mathbf{c m})$ & SDM $(\mathbf{g})$ \\
\hline Healthy control & $10.56 \mathrm{a}$ & $3.42 \mathrm{~b}$ & $13.98 \mathrm{a}$ & $0.026 \mathrm{c}$ \\
\hline Inoculated control & $7.70 \mathrm{~b}$ & $3.33 \mathrm{~b}$ & $11.04 \mathrm{~b}$ & $0.027 \mathrm{c}$ \\
\hline Fludyoxonyl & $8.96 \mathrm{a}$ & $3.34 \mathrm{~b}$ & $12.04 \mathrm{a}$ & $0.035 \mathrm{~b}$ \\
\hline Flutriafol & $6.69 \mathrm{~b}$ & $3.23 \mathrm{~b}$ & $9.92 \mathrm{~b}$ & $0.027 \mathrm{c}$ \\
\hline Tiophanate methyl & $8.44 \mathrm{~b}$ & $3.67 \mathrm{a}$ & $11.75 \mathrm{~b}$ & $0.045 \mathrm{a}$ \\
\hline SF 04 & $8.77 \mathrm{a}$ & $4.55 \mathrm{a}$ & $13.23 \mathrm{a}$ & $0.041 \mathrm{a}$ \\
\hline GF 422 & $9.96 \mathrm{a}$ & $4.37 \mathrm{a}$ & $14.33 \mathrm{a}$ & $0.040 \mathrm{a}$ \\
\hline Strain 1306 & $8.89 \mathrm{a}$ & $3.25 \mathrm{~b}$ & $12.14 \mathrm{a}$ & $0.035 \mathrm{~b}$ \\
\hline Fludyoxonyl+SF 04 & $10.23 \mathrm{a}$ & $3.69 \mathrm{a}$ & $13.81 \mathrm{a}$ & $0.037 \mathrm{~b}$ \\
\hline Fludyoxonyl+GF 422 & $10.25 \mathrm{a}$ & $4.19 \mathrm{a}$ & $13.88 \mathrm{a}$ & $0.045 \mathrm{a}$ \\
\hline Fludyoxonyl+Strain 1306 & $7.66 \mathrm{~b}$ & $2.78 \mathrm{~b}$ & $10.33 \mathrm{~b}$ & $0.031 \mathrm{c}$ \\
\hline Flutriafol+SF 04 & $7.30 \mathrm{~b}$ & $2.48 \mathrm{~b}$ & $9.79 \mathrm{~b}$ & $0.028 \mathrm{c}$ \\
\hline Flutriafol+GF 422 & $7.73 \mathrm{~b}$ & $3.28 \mathrm{~b}$ & $11.20 \mathrm{~b}$ & $0.035 \mathrm{~b}$ \\
\hline Flutriafol+Strain1306 & $7.08 \mathrm{~b}$ & $2.27 \mathrm{~b}$ & $9.35 \mathrm{~b}$ & $0.025 \mathrm{c}$ \\
\hline Tiophanate methyl+SF 04 & $9.55 \mathrm{a}$ & $3.24 \mathrm{~b}$ & $12.80 \mathrm{a}$ & $0.032 \mathrm{c}$ \\
\hline Tiophanate methyl+GF 422 & $8.26 \mathrm{~b}$ & $3.29 \mathrm{~b}$ & $11.55 \mathrm{~b}$ & $0.040 \mathrm{a}$ \\
\hline Tiophanate methyl+Strain 1306 & $6.56 \mathrm{~b}$ & $2.52 \mathrm{~b}$ & $9.08 \mathrm{~b}$ & $0.031 \mathrm{c}$ \\
\hline Mean & $8.50 \mathrm{~b}$ & $3.35 \mathrm{~b}$ & $11.78 \mathrm{~b}$ & $0.033 \mathrm{c}$ \\
\hline CV (\%) & 15.54 & 20.26 & 14.44 & 16.54 \\
\hline
\end{tabular}

Means followed by the same letter in the column do not differ by the Scott-Knott test ( $p<0.05)$; PR: primary root; S: shoot; TSL: total seedlings length; SDM: seedling dry matter; CV: coefficient of variation. 
Table 5. Emergence speed index, percentage of emergence at 8 days and 16 days from seedlings obtained from common bean seeds inoculated artificially with Fop and treated with chemical and biological products.

\begin{tabular}{lccc} 
Treatment & ESI & $\mathbf{E}_{8}(\%)$ & $\mathbf{E}_{16}(\%)$ \\
\hline Control without pathogen & $8.30 \mathrm{a}$ & $47 \mathrm{a}$ & $84 \mathrm{a}$ \\
\hline Control with pathogen & $6.55 \mathrm{~b}$ & $32 \mathrm{a}$ & $61 \mathrm{~b}$ \\
\hline Fludyoxonyl & $7.90 \mathrm{a}$ & $49 \mathrm{a}$ & $73 \mathrm{a}$ \\
\hline Flutriafol & $5.96 \mathrm{~b}$ & $40 \mathrm{a}$ & $60 \mathrm{~b}$ \\
\hline Tiophanate methyl & $7.50 \mathrm{a}$ & $32 \mathrm{a}$ & $66 \mathrm{~b}$ \\
\hline SF 04 & $7.00 \mathrm{~b}$ & $40 \mathrm{a}$ & $73 \mathrm{a}$ \\
\hline GF 422 & $7.08 \mathrm{~b}$ & $41 \mathrm{a}$ & $65 \mathrm{~b}$ \\
\hline Strain 1306 & $6.58 \mathrm{~b}$ & $50 \mathrm{a}$ & $72 \mathrm{a}$ \\
\hline Fludioxonil+SF 04 & $6.26 \mathrm{~b}$ & $43 \mathrm{a}$ & $68 \mathrm{a}$ \\
\hline Fludioxonil+GF 422 & $6.93 \mathrm{~b}$ & $44 \mathrm{a}$ & $69 \mathrm{a}$ \\
\hline Fludioxonil+Strain 1306 & $8.16 \mathrm{a}$ & $43 \mathrm{a}$ & $73 \mathrm{a}$ \\
\hline Flutriafol+SF 04 & $6.67 \mathrm{~b}$ & $36 \mathrm{a}$ & $72 \mathrm{a}$ \\
\hline Flutriafol+GF 422 & $5.75 \mathrm{~b}$ & $43 \mathrm{a}$ & $58 \mathrm{~b}$ \\
\hline Flutriafol+Strain 1306 & $6.77 \mathrm{~b}$ & $34 \mathrm{a}$ & $71 \mathrm{a}$ \\
\hline Tiophanate methyl+SF 04 & $7.02 \mathrm{~b}$ & $47 \mathrm{a}$ & $66 \mathrm{~b}$ \\
\hline Tiophanate methyl+GF 422 & $7.36 \mathrm{a}$ & $39 \mathrm{a}$ & $72 \mathrm{a}$ \\
\hline Tiophanate methyl+Strain 1306 & $7.67 \mathrm{a}$ & $43 \mathrm{a}$ & $74 \mathrm{a}$ \\
\hline Mean & $7.03 \mathrm{~b}$ & $42.02 \mathrm{a}$ & $68 \mathrm{~b}$ \\
\hline CV (\%) & 13.74 & 28.85 & 10.41 \\
\hline Means follow by the sametter & $4 \mathrm{col}$ & & \\
\hline
\end{tabular}

Means followed by the same letter in the column do not differ by the Scott-Knott test $(p<0.05)$; ESI: emergence speed index; E8: percentage of emergence at 8 days; E16: percentage of emergence at 16 days; $\mathrm{CV}$ : coefficient of variation.
However, most studies report the transmission of Fop mainly through artificial or naturally infected seeds, with little information about the transmission of the fungus via soil. SOUSA (2014) when verifying the Fop transmission from artificially inoculated seeds to seedlings, detected more pathogen colonization in the hypocotyl than in the roots, cotyledons and first internode. His work stated Fop colonization of 55.8 and $57.6 \%$, respectively, at temperatures of 20 and $25^{\circ} \mathrm{C}$ in the hypocotyl region. Previously, the efficiency of transmission of Fop was published by SANTOS et al. (1996), whose study showed that common bean seeds infected with $14 \%$ of pathogen, were able to cause $42.8 \%$ of pathogen colonization in plants.

Considering the pathosytem of this present study, which has only two chemical fungicides recommended for seed treatment, the results obtained prove the compatibility between chemical fungicides and products based on Trichoderma spp. In addition to disease control itself, many Trichoderma strains are also capable of degrading chemical fungicide molecules, making the simultaneous use of chemical and biological fungicides a viable practice, considering the integrated management of diseases (ALVARENGA et al., 2007). In this strategy, according to MELO et al. (2001), sublethal doses of the active ingredients weaken the phytopathogen structures, making it more susceptible to the action of the antagonist and, after having performed its function, is degraded by Trichoderma. Data published by the same authors revealed that the Trichoderma genus is able to degrade matalaxyl when inhibiting Phytophthora parasitica and P. citrophthora. In this way, it is advisable to notice how seed treatment is done in the field, considering the biocontrol agent viability after its

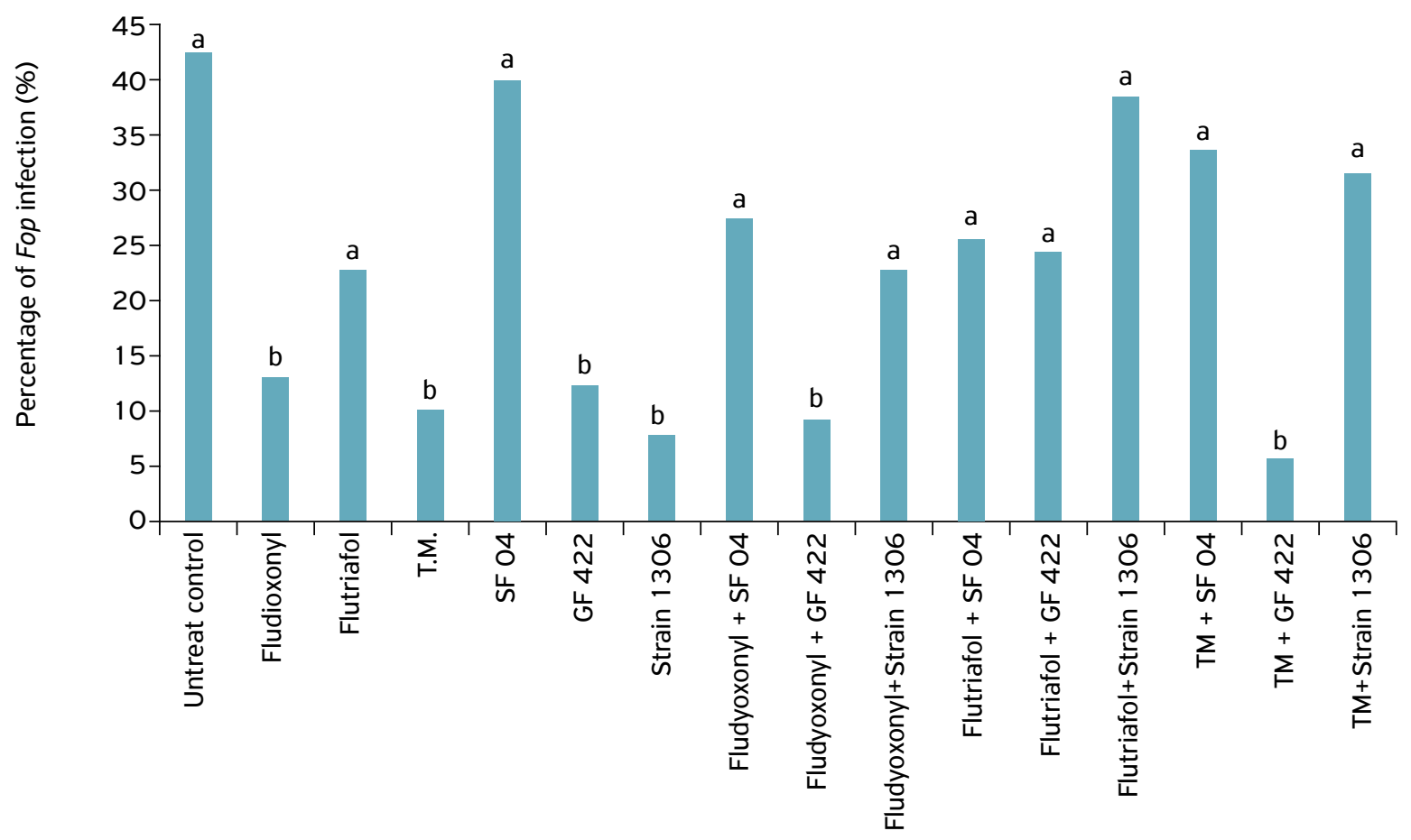

Figure 1. Percentage of Fop transmission from infested substrate to hypocotyl in common bean seedlings at 25 days after sowing. 


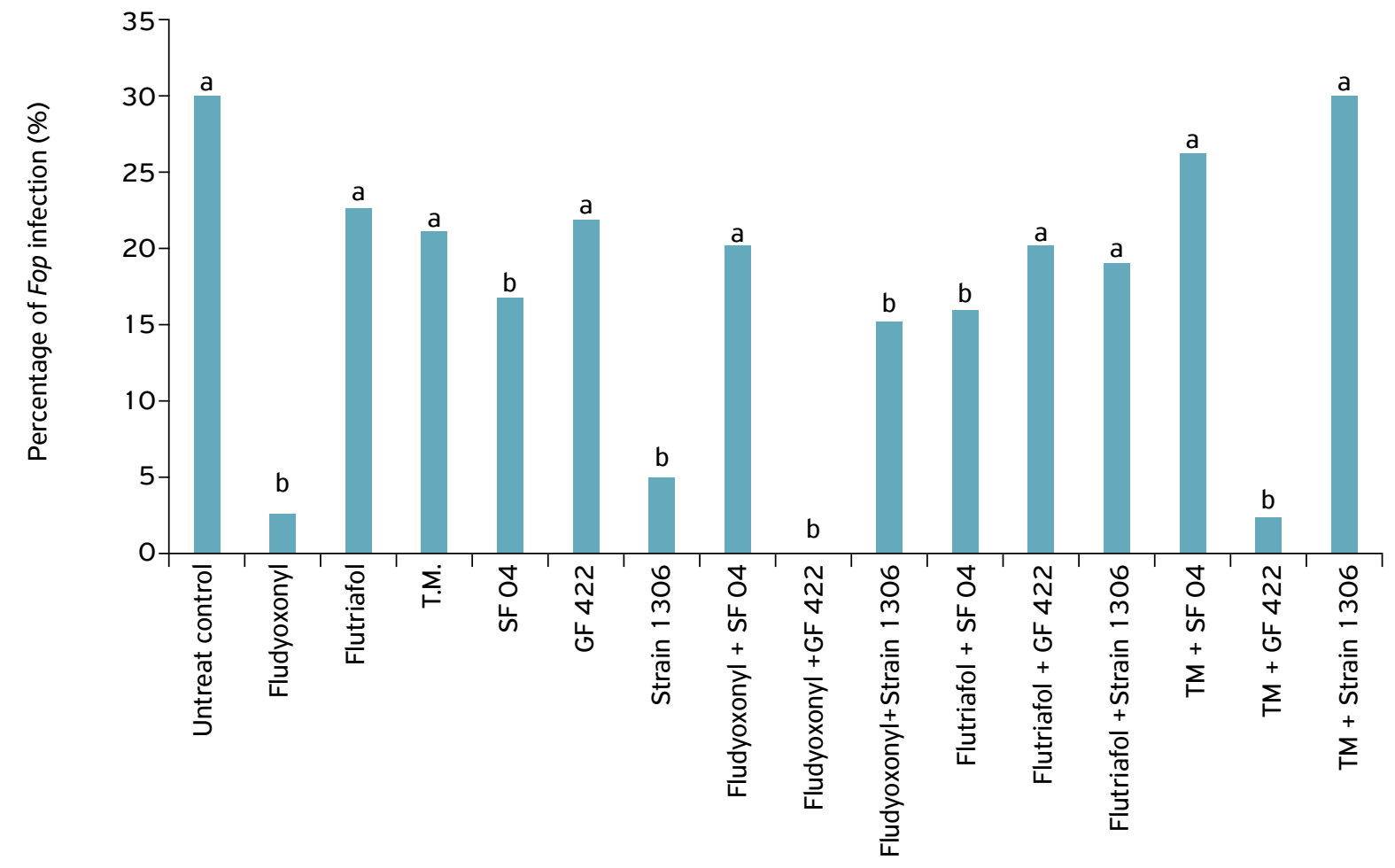

Figure 2. Percentage of Fop transmission from infested substrate to main root of common bean plants after 25 days of sowing.

contact with chemical fungicide. In the present work, the protective effect of Trichoderma was not affected, although the products were put in a single mixture. Considering the situations in which the chemical fungicide is applied to the seeds at first and then followed by the biological products, it is expected that there is more viability and efficiency promoted by the biocontrol agent.

Correlating the results with experiments performed from artificially inoculated seeds with the transmission test, higher efficiency of treatments in terms of eradication of pathogens associated with seeds, with little protective effect of these treatments in relation to the inoculum present in the substrate.

\section{CONCLUSIONS}

The treatments that promoted the best pathogen control were the combination of methyl thiophanate with biological products, which reduced 91 and 95\% Fop incidence in the seeds. In the transmission test, the treatments fludyoxonyl, strain 1306, fludyoxonyol+GF422, and tiophanate methyl+GF422 reduced the pathogen incidence in both root and shoot.

In the present work, the use of chemical and biological treatments did not affect the physiological quality of common bean seeds, except for flutriafol and GF 422 used in an isolated and mixtured way.

ACKNOWLEDGMENTS: The authors would like to thank the companies, Grupo Farroupilha and Koppert do Brasil for making available the biological products evaluated in this study.

FUNDING: This study was funded by Brazilian agencies Conselho Nacional de Desenvolvimento Científico e Tecnológico (CNPq) for the scholarships and financial support granted. This study was partly financed by Coordenação de Aperfeiçoamento de Pessoal de Nível Superior - Brasil (CAPES), Finance Code 001.

CONFLICTS OF INTEREST: The authors certify that they have no commercial or associative interest that represents a conflict of interest in connection with the manuscript.

ETHICAL APPROVAL: Not applicable.

AVAILABILITY OF DATA AND MATERIAL: The datasets generated and/or analyzed during the current study are available in the Biblioteca Digital da USP (https://www.teses.usp.br/teses/disponiveis/11/11135/tde-10062016-095344/pt-br.php).

AUTHORS' CONTRIBUTIONS: Conceptualization, Data curation, Formal analysis, Funding acquisition, Investigation, Methodology, Project administration, Resources, Software, Supervision, Validation, Visualization, Writing - original draft: Ishizuka, M.S; Linhares, R.; Moraes, M.H.D; Menten, J.O.M. Writing - review \& editing: Ishizuka, M.S.; Moraes, M.H.D. 

REFERENCES

ALVARENGA, D.O.; QUEIROZ, P.R.; ALMEIDA, A.M.; MELLO, S.C.M. Aspectos relacionados ao controle biológico do mofo branco causado por Sclerotinia sclerotiorum (Boletim de Pesquisa e Desenvolvimento, 168). Brasília: Embrapa Recursos Genéticos e Biotecnologia, 2007. 24p.

ALWATHNANI, H.A.; PERVEEN, K.; TAHMAZ, R.; ALHAQBANI, $S$. Evaluation of biological control potential of locally isolated antagonist fungi against Fusarium oxysporum under in vitro and pot conditions. African Journal of Microbiology Research, Nairobi, v.6, n.2, p.312-319, 2012. https://doi.org/10.5897/AJMR1 1.1367

BRAND, S.C.; ANTONELLO, L.M.; MUNIZ, M.F.B.; BLUME, E.; SANTOS, V.J.; REINIGER, L.R.S. Qualidade sanitária e fisiológica de sementes de soja submetidas a tratamento com bioprotetor e fungicida. Revista Brasileira de Sementes, Londrina, v.31, n.4, p.87-94, 2009. https://doi.org/10.1590/SO101-31222009000400010

BRASIL. Ministério da Agricultura, Pecuária e Abastecimento. Manual de análise sanitária de sementes. Brasília: MAPA, ACS, 2009a. 200p.

BRASIL. Regras para análise de sementes. Brasília: Secretaria de Defesa Agropecuária, 2009b. 399p.

CANTERI, M.G.; PRIA, M.D.; SILVA, O.C. Principais doenças fúngicas para manejo econômico e ecológico. Ponta Grossa: UEPG, 1999. 178p.

CARVALHO, D.D.C.; MELLO, S.C.M.; LOBO JUNIOR, M.; SILVA, M.C. Controle de Fusarium oxysporum f.sp. phaseoli in vitro e em sementes, e promoção do crescimento inicial do feijoeiro comum por Trichoderma harzianum. Tropical Plant Pathology, Brasília, v.36, n.1, p.36-42, 2011 . https://doi.org/10.1590/ S1982-56762011000100004

CHAUDHARY, S.; ANDERSON, T.R.; PARK, S.J.; YU, K. Comparison of screening methods for resistance to Fusarium root rot in common beans (Phaseolus vulgaris L.). Journal of Phytopathology, Berlin, v.154, n.5, p.303-308, 2006. https:// doi.org/10.1111/j.1439-0434.2006.01097.x

COMISSÃO TÉCNICA SUL-BRASILEIRA DE FEIJÃO. Informações técnicas para o cultivo de feijão na Região Sul brasileira. 2. ed. Florianópolis: Epagri, 2012. 157p.

COMPANHIA NACIONAL DE ABASTECIMENTO (CONAB). Acompanhamento da safra brasileira de grãos, Conab, Brasília, v.7, safra 2019/20, p.60, 2019. Available from: https://www. conab.gov.br/info-agro/safras/graos. Access on: Jan. 212020.

COSTA, M.L.N.; MACHADO, J.C; GUIMARÃES, R.M.; POZZA, E.A.; ORIDE, D. Inoculação de Fusarium oxysporum f. sp. phaseoli em sementes de feijoeiro através de restrição hídrica. Ciência Agrotecnológica, Lavras, v.27, n.5, p.1023-1030, 2003. https:// doi.org/10.1590/S1413-70542003000500008

DHINGRA, O.D.; NETTO, R.A.C. Reservoir and non-reservoir hosts of bean-wilt pathogen, Fusarium oxysporum f. sp. phaseoli. Journal of Phytopathology, Berlin, v.149, n.7-8, p.463-467, 2001. https://doi.org/10.1111/j.1439-0434.2001.tb03878.x
EL-ABYAD, M.; EL-SAYED, M.A.; EL-SHANSHOURY, A.R.; EL-SABBAGH, S.H. Towards the biological control of fungal and bacterial diseases of tomato using antagonistic Streptomyces spp. Plant and Soil, Dordrecht, v.149, n.2, p.185-195, 1993. https://doi.org/10.1007/BFO0016608

FAOSTAST. Rome. 2019. Available from: http://www.fao.org/ faostat/en/\#data/QC. Access on: Jan. 222020.

FORCELINI, C.A. Importância epidemiológica de fungos do gênero Helminthosporium em sementes de trigo e cevada. In: MENTEN, J.O.M. (Ed.) Patógenos em sementes - detecção, danos e controle químico. Piracicaba: ESALQ/FEALQ, 1991. p.179-190.

HOWELL, C.R. The role of antibiosis. In: HARMAN, G.E.; KUBICEK, C.P. (Ed.). Trichoderma and Gliocladium. v. 2. Enzymes, biological control, and commercial applications. London: Taylor \& Francis, 2007. p. 173-184.

GUIMARÃES, E.P.; SOUZA, T.L.P.O. Common bean. Pelotas, 2019. Available from: http://seednews.com.br/edicoes/artigo/2917common-bean-edicao-janeiro-2019. Access on: Jan. 222020.

LUZ, W.C. Avaliação dos tratamentos biológico e químico na redução de patógenos em sementes de trigo. Fitopatologia Brasileira, Brasília, v.28, n.1, p.93-95, 2003. https://doi.org/10.1590/ SO $100-41582003000100014$

MACE, M.E.; BELL A.A.; BECKMAN C.H. Fungal wilt diseases of plants. New York: Academic Press, 1981.640p.

MAGUIRE, J.D. Speed of germination: aid in selection and evaluation for seedling emergence and vigor. Crop Science, Madison, v.2, n. 1, p.176-177, 1962. http://dx.doi.org/10.2135/cropsci 19 62.0011183X000200020033x

MELO, I.S. Potencialidades de utilização de Trichoderma spp. no controle biológico de doenças de plantas. In: BETTIOL, W. (Org.) Controle biológico de doenças de plantas. Jaguariúna: Embrapa CNPDA, 1991.p.135-156.

MELO, I.S.; LEVANTEZI, K.; SPESSOTO, A.M.; FEICHTENBERGER, E. Degradação do fungicida metalaxial por linhagens de Trichoderma spp. isoladas de solos rizosféricos. In: MELO, I.S.; SILVA, C.M.M.S.; SCRAMIN, S.; SPESSOTO, A. (Org.). Biodegradação. Jaguariúna: Embrapa Meio Ambiente, 2001. p.141-165.

MERTZ, L.M.; HENNING, F.A.; ZIMMER, P.D. Bioprotetores e fungicidas químicos no tratamento de sementes de soja. Ciência Rural, Lavras, v.39, n.1, p.13-18, 2009. https://doi.org/10.1590/ s0103-84782009000100003

MORANDI, M.A.B.; BETTIOL, W. Controle biológico de doenças de plantas no Brasil. In: BETTIOL, W.; MORANDI, M.A.B. (Ed.). Biocontrole de doenças de plantas: uso e perspectivas. Jaguariúna: Embrapa Meio Ambiente, 2009. p.7-14.

NAKAGAWA, J. Testes de vigor baseados no desempenho das plântulas. In: KRZYZANOWSKI, F.C.; VIEIRA, R.D.; FRANÇA NETO, J.B. (Ed.). Vigor de sementes: conceitos e testes. Londrina: ABRATES, 1999. p. 2.9-2.13. 
PAULA JÚNIOR, T.J.; VIEIRA, R.F.; ZAMBOLIM, L.M. Manejo integrado de doenças do feijoeiro. Informe Agropecuário, Belo Horizonte, v. 25, n.223, p.99-112, 2004.

SANTOS, G.R.; COSTA, H.; PELUZIO, J.M.; MIRANDA, G.V. Transporte, transmissibilidade e patogenicidade da micoflora associada às sementes de feijão (Phaseolus vulgaris L.). Revista Ceres, Viçosa, v.43, n.249, p.621-627, 1996.

SILVA, F.A.S.; AZEVEDO, C.A.V. Versão do programa computacional Assistat para o sistema operacional Windows. Revista Brasileira de Produtos Agroindustriais, Campina Grande, v.4, n. 1, p 71-78, 2002.
SOUSA, M.V. Transmission, colonization and molecular detection of Fusarium oxysporum f. sp. phaseoli in common bean seeds. 2014. 119p. Thesis (Doctorate in Agronomy / Phytopathology) - Universidade Federal de Lavras, Lavras, 2014. Available from: http://repositorio.ufla.br/jspui/handle/1/1715. Access on: Nov. 272015.

VANIN, A.; SILVA, A.G.; FERNANDES, C.P.C.; FERREIRA, W.S.; RATTES, J.F. Tratamento de sementes de sorgo com inseticidas. Revista Brasileira de Sementes, Londrina, v.33, n.2, p.299-309, 2011 .https://doi.org/10.1590/SO101-31222011000200012

VIEIRA, C. Doenças e pragas do feijoeiro. Viçosa: UFV, 1993. $231 \mathrm{p}$. 